\title{
Lasiodiplodia pseudotheobromae causes pedicel and peduncle discolouration of grapes in China
}

\author{
Asha J. Dissanayake ${ }^{1,2} \cdot$ Wei Zhang ${ }^{1} \cdot$ Liu Mei $^{1} \cdot$ Ekachai Chukeatirote $^{2}$. \\ Ji Ye Yan ${ }^{1}$ XingHong $\mathrm{Li}^{1} \cdot$ Kevin D. Hyde ${ }^{2}$
}

Received: 2 March 2015 / Accepted: 11 May 2015 / Published online: 4 June 2015

(C) Australasian Plant Pathology Society Inc. 2015

\begin{abstract}
A botryosphaeriaceous taxon causing fruit peduncle and pedicel discolouration was found infecting grapevines in Hubei and Jiangsu Provinces in China. Morphological and phylogenetic analyses showed the taxon to be Lasiodiplodia pseudotheobromae. Pathogenicity testing and Koch's postulates proved that Lasiodiplodia pseudotheobromae caused fruit peduncle and pedicel discolouration on grape fruit clusters. This is the first report of this fungus causing grapevine fruit peduncle and pedicel discolouration worldwide.
\end{abstract}

Keywords Botryosphaeriaceae $\cdot$ Pathogenicity $\cdot$ Pedicel discolouration · Vitis vinifera

Grapes have been grown in China for more than 2000 years and grape production has increased rapidly, especially since the 1980's (Li 2001). Grapevine trunk diseases cause great economic losses in the wine and grape industries across the world (Úrbez-Torres 2011). Botryosphaeriaceous pathogens associated with grapevine trunk diseases cause severe and economically significant symptoms (Crous et al. 2006; Úrbez-Torres 2011; Yan et al. 2013). The genera Botryosphaeria, Diplodia, Lasiodiplodia and Neofusicoccum were reported to be the prominent genera of

Asha J. Dissanayake and Wei Zhang contributed equally to this work.

XingHong Li

lixinghong1962@163.com

1 Institute of Plant and Environment Protection, Beijing Academy of Agriculture and Forestry Sciences, Beijing 100097, China

2 Institute of Excellence in Fungal Research and School of Science, Mae Fah Luang University, Chiang Rai 57100, Thailand
Botryosphaeriaceae associated with grapevine infections (Luque et al. 2009; van Niekerk et al. 2006; Úrbez-Torres 2011). Presently 25 Botryosphaeriaceae species are known from grapevine worldwide (Úrbez-Torres 2011; Linaldeddu et al. 2014; Dissanayake et al., First report of Neofusicoccum mangiferae associated with grapevine dieback in China (unpublished)). Morphological and multi-gene phylogenetic analyses confirmed Botryosphaeria dothidea, Diplodia seriata, Lasiodiplodia theobromae and Neofusicoccum parvum were associated with different grapevine dieback symptoms in Chinese vineyards (Yan et al. 2013). Lasiodiplodia pseudotheobromae is reported for the first time on grapevine in Brazil as a grapevine trunk pathogen (Correia et al. 2013). The symptoms caused by Botryosphaeriaceae on grapevines are significantly different between countries and vary depending on the cultivars. The most serious symptom reported in Chinese grapevines are 'cluster and fruit dropping' which differs to the major symptoms described in other countries (Yan et al. 2013).

In June-August 2013, the disease was observed on grape clusters (E-L33) in Jiangsu and Hubei Provinces in China. The symptoms appeared on fruit peduncles and pedicels in grape clusters as small, brown necrotic lesions which expanded and later became dry and dead (Fig. 1). Symptomatic grape clusters were collected; the tissues were cut into $5 \mathrm{~mm}$ pieces from the margins of healthy and infected tissues and surface-sterilized by immersion in $2 \% \mathrm{NaOCl}$ for $1 \mathrm{~min}$. The cuttings were rinsed three times in sterile distilled water, dried and placed on potato dextrose agar (PDA) medium and incubated at $28{ }^{\circ} \mathrm{C}$ for 7 days. Isolates developed from the diseased tissues were sub-cultured on PDA medium and purified via single spore isolation. Representative cultures were deposited at the Mae Fah Luang University culture collection (MFLUCC), Thailand (Table 1).

Identification of the fungus was based on both morphological characteristics and molecular methods. Conidiomata 


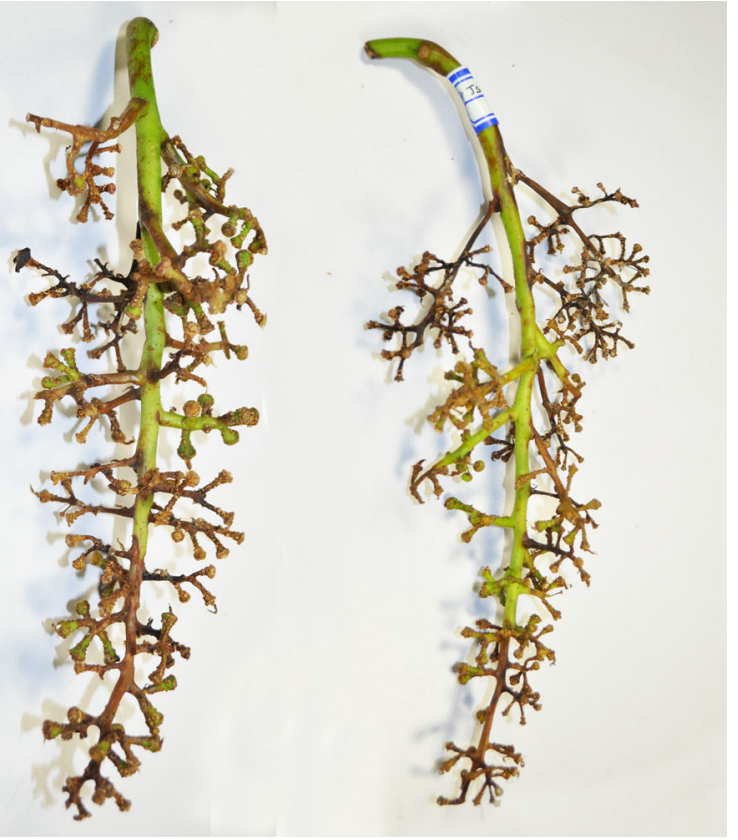

Fig. 1 Peduncle and pedicel discolouration of grape clusters

obtained from the culture plates were mounted in microscopic slides and the dimensions of 40 conidia were measured with Nikon DS-RiI digital camera connected to a Nikon NISElements F3.0 microscope.

The genomic DNA was extracted from pure cultures grown on PDA following the CTAB method of Doyle and Doyle (1987). DNA amplification was performed by polymerase chain reaction (PCR). Primer pairs ITS1 and ITS5 (White et al. 1990) were used to amplify the internal transcribed spacers. Primers EF1-728F and EF1-986R (Carbone and Kohn 1999) and Bt2a and Bt2b (Glass and Donaldson 1995) were used to amplify and sequence part of the translation elongation factor 1alpha $(E F 1-\alpha)$ gene and part of the $\beta$-tubulin gene respectively. Sequences were aligned with those retrieved from GenBank (Table 1) using MAFFT v. 6.0 (Katoh and Toh 2010) and manually adjusted when necessary. Maximum parsimony analysis (MP) was performed with PAUP* (Phylogenetic Analysis Using Parsimony) v. $4.0 \mathrm{~b} 10$ (Swofford 2003) using the heuristic search option with 1000 random stepwise addition. The nucleotide substitution models were determined individually for each gene region using MrModelTest v. 2.3 (Nylander 2004). A Bayesian analysis was performed using MrBayes v. 3.1.2 (Ronquist and Huelsenbeck 2003). Sequences generated in this study are deposited in GenBank (Table 1). Resulting alignment and the tree were deposited in TreeBASE (http://www.treebase.org/) as accession number S16881.

Pathogenicity was assessed for grape fruit clusters (E-L36) cv. Niunai. Grape clusters were surface sterilized with $1 \%$ $\mathrm{NaOCl}$ and washed three times in sterilized water. Six peduncles and six pedicels were punctured with a sterile needle. Mycelial plugs (3-5 $\mathrm{mm}^{2}$ ) taken from the margin of an

Table 1 Isolates used in this study. GenBank accession numbers of Lasiodiplodia pseudotheobromae obtained in this study are in italic

\begin{tabular}{|c|c|c|c|c|c|c|}
\hline \multirow[t]{2}{*}{ Lasiodiplodia species } & \multirow[t]{2}{*}{ Isolate number } & \multirow[t]{2}{*}{ Origin } & \multirow[t]{2}{*}{ Host } & \multicolumn{3}{|c|}{ GenBank accession numbers } \\
\hline & & & & ITS & $\mathrm{EF} 1-\alpha$ & $\beta$-tubulin \\
\hline Diplodia mutila & CBS 112553 & - & Vitis vinifera & AY259093 & AY573219 & DQ458850 \\
\hline L. citricola & CBS 124707 & Iran & Citrus sp. & GU945354 & GU945340 & - \\
\hline L. egyptiacae & CBS 130992 & Egypt & Mangifera indica & JN814397 & JN814424 & - \\
\hline L. euphorbicola & CMM3609 & Brazil & Jatropha curcas & KF234543 & KF226689 & KF254926 \\
\hline L. hormozganensis & CBS 124709 & Iran & Olea sp. & GU945355 & GU945343 & - \\
\hline L. macrospora & CMM3833 & Brazil & Jatropha curcas & KF234557 & KF226718 & KF254941 \\
\hline L. marypalme & CMM 2275 & Brazil & Carica papaya & KC484843 & KC481567 & - \\
\hline L. parva & CBS 456.78 & Portugal & Cassava-field soil & EF622083 & EF622063 & - \\
\hline L. pseudotheobromae & CBS 116459 & Costa Rica & Gmelina arborea & EF622077 & EF622057 & EU673111 \\
\hline L. pseudotheobromae & MFLUCC 14-1192 & Hubei, China & Vitis vinifera & KP319266 & KP319264 & KP319260 \\
\hline L. pseudotheobromae & MFLUCC 14-1193 & Hubei, China & Vitis vinifera & KP319267 & KP319265 & KP319261 \\
\hline L. pseudotheobromae & MFLUCC 14-1194 & Jiangsu, China & Vitis vinifera & KP319268 & KP319262 & KP319258 \\
\hline L. pseudotheobromae & MFLUCC 14-1195 & Jiangsu, China & Vitis vinifera & KP319269 & KP319263 & KP319259 \\
\hline L. subglobosa & CMM3872 & Brazil & Jatropha curcas & KF234558 & KF226721 & KF254942 \\
\hline L. theobromae & CBS 164.96 & Portugal & Fruit on coral reef & AY640255 & AY640258 & EU673110 \\
\hline
\end{tabular}


actively growing colony on PDA (isolate MFLUCC 14-1192) was placed on the wounded peduncles and pedicels. Sterile PDA plugs were placed on punctured peduncles and pedicels as controls. Wounds were sealed and wrapped with parafilm (BEMIS, USA). Inoculated grape clusters were maintained at $28{ }^{\circ} \mathrm{C}$ and $70 \% \mathrm{RH}$ under $12 \mathrm{~h}$ light $/ 12 \mathrm{~h}$ dark system for 5 days.

Colonies on PDA were initially grey-white and became dark grey-black when aged with a sporulation after 15 days. Conidia were $25-30 \times 10-15 \mu \mathrm{m}(n=40)$, hyaline, aseptate, sub-ovoid to ellipsoid with broadly rounded apices and later became dark brown, 1-septate and thick-walled (Fig. 2). Conidial morphology and cultural features of the isolates are in close agreement with the morphological description of $L$. pseudotheobromae (Alves et al. 2008).

Amplicons of the ITS, EF $1-\alpha$ and $\beta$-tubulin regions have approximately $0.5,0.3$, and $0.4 \mathrm{kbp}$, respectively. The combined dataset of ITS, EF $1-\alpha$ and $\beta$-tubulin consisted of 15 taxa, which comprised the four L. pseudotheobromae isolates obtained in this study and 11 additional isolates (Hyde et al. 2014) including the outgroup Diplodia mutila. The combined dataset comprised 1180 characters after the uneven ends were truncated. Of these characters, 1034 were constant, 111 were parsimony uninformative and 35 were parsimony informative. A heuristic search revealed most parsimonious trees (Fig. 3; tree length $=176$ steps, $\mathrm{CI}=0.898$, $\mathrm{RI}=0.822, \mathrm{RC}=0.738$ and $\mathrm{HI}=102)$. Maximumparsimony and Bayesian inference produced trees with nearly identical topologies (Bayesian tree not shown). Isolates obtained in this study clustered together in a wellsupported clade (bootstrap value $=100 \%$; posterior probability $=1.0$ ) with the ex-type of L. pseudotheobromae (CBS 116459) thus confirming the identification of the studied isolates.

Disease symptoms developed on the inoculated fruit peduncles and pedicels within $24 \mathrm{~h}$ after inoculation. At the end of the third day, grey-white mycelia were observed on affected areas (Fig. 4). The pathogen was reisolated from the lesions on peduncles to confirm Koch's postulates. No disease symptoms were observed on the control fruit clusters.

On the basis of morphological characteristics, pathogenicity testing on host plant, and molecular analysis, the fungus was identified as L. pseudotheobromae. This species
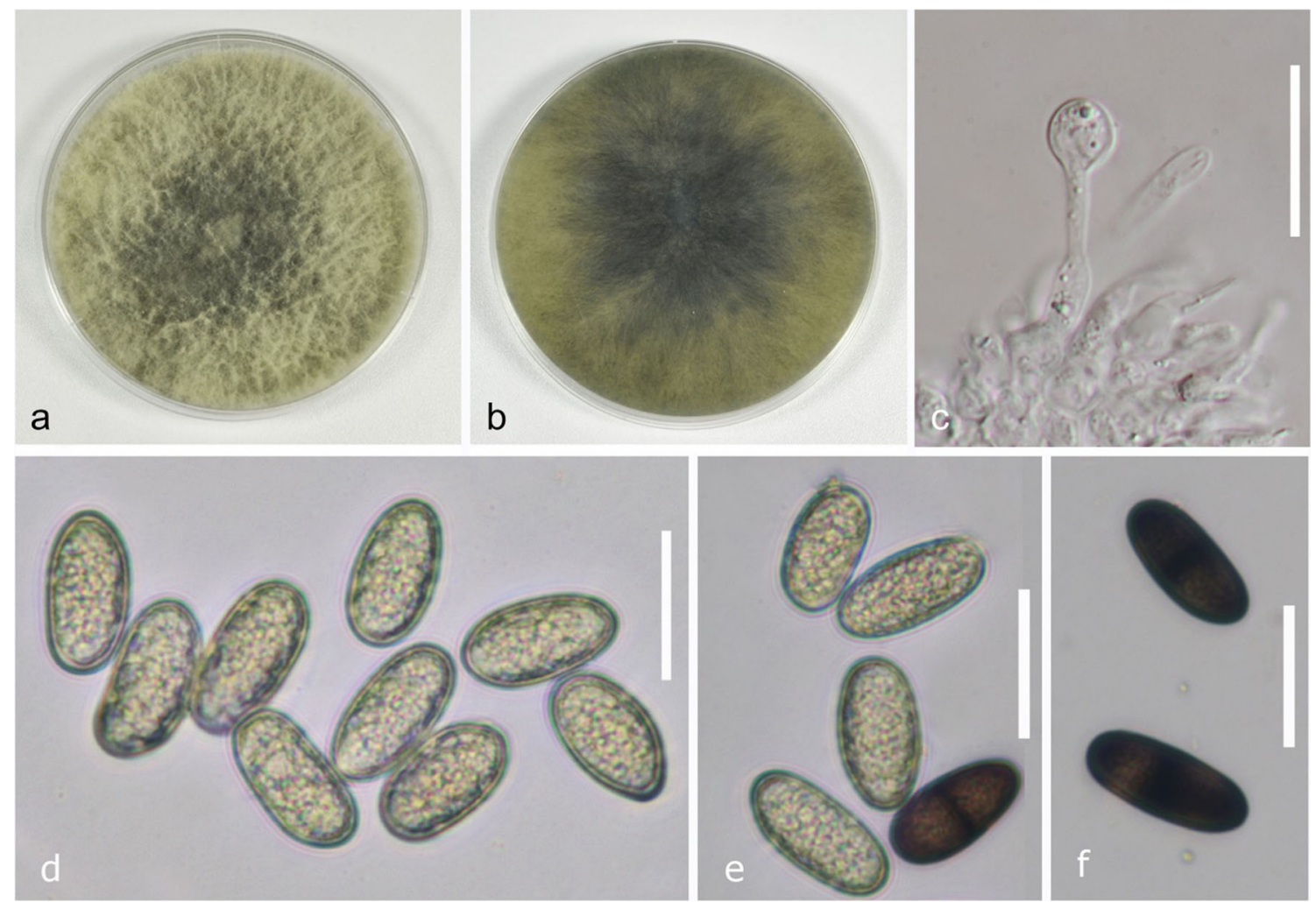

Fig. 2 Lasiodiplodia pseudotheobromae. Upper view of the 10 days older culture (a). Reverse view of the 10 days older culture (b). Conidiogenous cells (c). Young conidia (d). Young and mature conidia (e). Mature conidia (f) Scale bars $=30 \mu \mathrm{m}(\mathbf{c}, \mathbf{d}, \mathbf{e}, \mathbf{f})$ 
Fig. 3 Phylogenetic analysis of the combined dataset of ITS, EF1$\alpha$ and $\beta$-tubulin sequences alignment. The scale bar shows 1 change. Bootstrap support values for maximum parsimony (MP) greater than $95 \%$ and Bayesian posterior probabilities above 0.95 are given above the nodes. Isolate numbers follow species names, with ex-type and ex-epitype strains in bold. The tree is rooted to Diplodia mutila (CBS 112553)

Fig. 4 Pathogenicity test of Lasiodiplodia pseudotheobromae on grape fruit peduncles and pedicels. Non-inoculated fruit cluster (a). Fungal mycelium spreading over the fruit peduncles and pedicels, $72 \mathrm{~h}$ after inoculation (b)
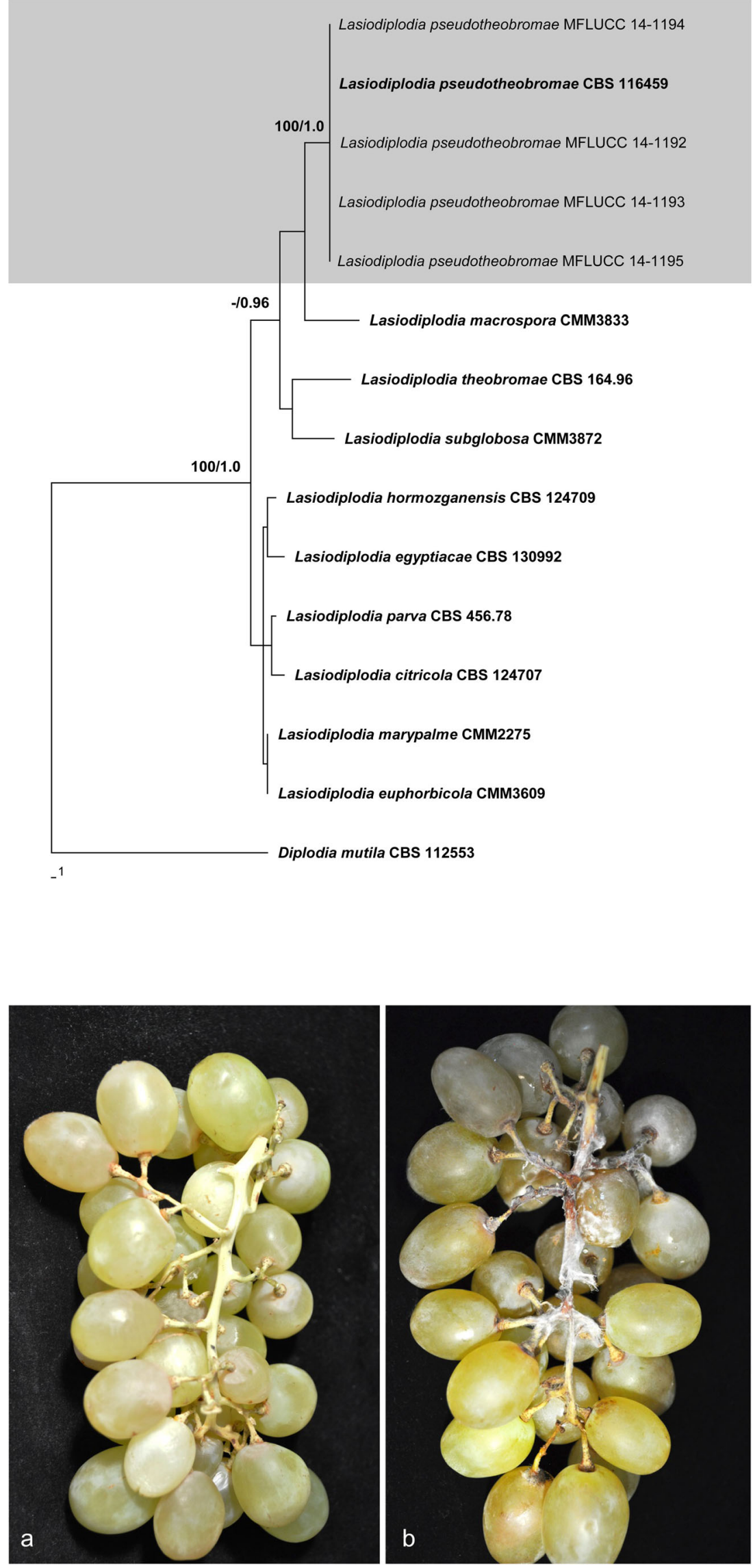
was previously reported in China on Acacia confusa, Albizia falcataria, Eucalyptus sp., Mangifera sylvatica and Paulownia fortunei (Zhao et al. 2010). To our knowledge, this is the first report of Lasiodiplodia pseudotheobromae causing grapevine fruit peduncle and pedicel discolouration worldwide.

Acknowledgments The study is funded by CARS-30 and CXJJ201402.

\section{References}

Alves A, Crous PW, Correia A, Phillips AJL (2008) Morphological and molecular data reveal cryptic speciation in Lasiodiplodia theobromae. Fungal Divers 28:1-13

Carbone I, Kohn LM (1999) A method for designing primer sets for speciation studies in filamentous ascomycetes. Mycologia 91:553556

Correia KC, Camara MPS, Barbosa MAG, Sales Jr R, Augusti-Brisach C, Gramaje D, Leon M, Garcia-Jimenez J, Abad-Campos P, Armengol J, Michereff SJ (2013) Fungal trunk pathogens associated with table grape decline in Northeastern Brazil. Phytopathol Mediterr 52:380-387

Crous PW, Slippers B, Wingfield MJ, Reeder J, Marasas WFO, Phillips AJL, Alves A, Burgess T, Barber P, Groenewald JZ (2006) Phylogenetic lineages in the Botryosphaeriaceae. Stud Mycol 55: 235-253

Doyle JJ, Doyle JL (1987) A rapid DNA isolation procedure for small quantities of fresh leaf tissue. Phytochem Bull 19:11-15

Glass NL, Donaldson GC (1995) Development of primer sets designed for use with the PCR to amplify conserved genes from filamentous ascomycetes. Appl Environ Microbiol 61:1323

Hyde KD, Nilsson RH, Alias SA, Ariyawansa HA, Blair JE, Cai L, de Cock AWAM, Dissanayake AJ, Glockling SL, Goonasekara ID, Gorczak M, Hahn M, Jayawardena RS, van Kan JAL, Laurence MH, Lévesque CA, Li XH, Liu JK, Maharachchikumbura SSN, Manamgoda DS, Martin FN, McKenzie EHC, McTaggart AR, Mortimer PE, Nair PVR, Pawłowska J, Rintoul TL, Shivas RG, Spies CFJ, Summerell BA, Taylor PWJ, Terhem RB, Udayanga
D, Vaghefi N, Walther G, Wilk M, Wrzosek M, Xu JC, Yan JY, Zhou N (2014) One stop shop: backbones trees for important pytopathogenic genera: I. Fungal Divers 67:21-125

Katoh K, Toh H (2010) Parallelization of the MAFFT multiple sequence alignment program. Bioinformatics 26:1899-1900

Li S (2001) Grape production in China. In: Papademetriou MK, Dent FJ (eds) Grape production in the Asia-Pacific region. Food and Agricultural Organization of the United Nations, Regional Office for Asia and the Pacific, Bangkok, pp. 19-27

Linaldeddu BT, Deidda A, Scanu B, Franceschini A, Serra S, BerrafTebbal A, Zouaoui Boutiti M, Jamâa MLB, Phillips AJL (2014) Diversity of Botryosphaeriaceae species associated with grapevine and other woody hosts in Italy, Algeria and Tunisia, with descriptions of Lasiodiplodia exigua and Lasiodiplodia mediterranea sp. nov. Fungal Divers. doi:10.1007/s13225-014-0301-x

Luque J, Martos S, Aroca A, Raposo R, Garcia-Figueres F (2009) Symptoms and fungi associated with declining mature grapevine plants in Northeast Spain. J Plant Pathol 91:381-390

Nylander JAA (2004) MrModeltest v2. Program distributed by the author. Evolutionary Biology Centre, Uppsala University, Sweden

Ronquist F, Huelsenbeck JP (2003) MRBAYES 3: Bayesian phylogenetic inference under mixed models. Bioinformatics 19:1572-1574

Swofford DL (2003) PAUP*. Phylogenetic analysis using parsimony (and other methods). Version 4. Sinaur Associates, Sunderland

Úrbez-Torres JR (2011) The status of Botryosphaeriaceae species infecting grapevines. Phytopathol Mediterr 50:5-45

van Niekerk JM, Fourie P, Halleen F, Crous PW (2006) Botryosphaeria spp. as grapevine trunk disease pathogens. Phytopathol Mediterr 45: S43-S54

White TJ, Bruns T, Lee S, Taylor J (1990) Amplification and direct sequencing of fungal ribosomal RNA genes for phylogenies. In: Innis MA, Gelfand DH, Sninsky JJ, White TI (eds) PCR protocols: a guide to methods and applications. Academic Press, San Diego, pp. 315-322

Yan JY, Xie Y, Zhang W, Wang Y, Liu JK, Hyde KD, Seem RC, Zhang GC, Wang ZY, Yao SW, Bai XJ, Dissanayake AJ, Peng YL, Li XH (2013) Species of Botryosphaeriaceae involved in grapevine dieback in China. Fungal Divers 61:221-236

Zhao JP, Lu Q, Liang J, Decock C, Zhang XY (2010) Lasiodiplodia pseudotheobromae, a new record of pathogenic fungus from some subtropical and tropical trees in southern China. Cryptogam Mycol $31: 431-439$ 